\title{
PSA Level Greater than or Equal to 0.1
}

National Cancer Institute

\section{Source}

National Cancer Institute. PSA Level Greater than or Equal to 0.1. NCI Thesaurus. Code C138940.

A blood concentration of prostate specific antigen greater than or equal to $0.1 \mathrm{ng} / \mathrm{mL}$. 